\title{
A Química: O Primeiro Século na Universidade de Coimbra e o Progresso desta Ciência
}

\begin{abstract}
Sobre o Livro
A matriz reflexiva deste escrito é constituída pela evolução da Química na Universidade de Coimbra e nos países cientificamente mais avançados no decurso do primeiro século desta ciência, no que respeita à história das ideias e às condições necessárias para o seu progresso, tais como as técnicas laboratoriais, o interesse social e a sua capacidade de associação. 0 estudo comparativo do desenvolvimento da Química no nosso País e o crescimento explosivo da ciência no plano internacional não deixa também de ser objeto de análise crítica na economia da obra. 0 declínio da Universidade ao tempo da criação da cadeira de Química e a fase pré-científica desta disciplina são apresentadas como introdução necessária à avaliação científica do período em apreço.
\end{abstract}

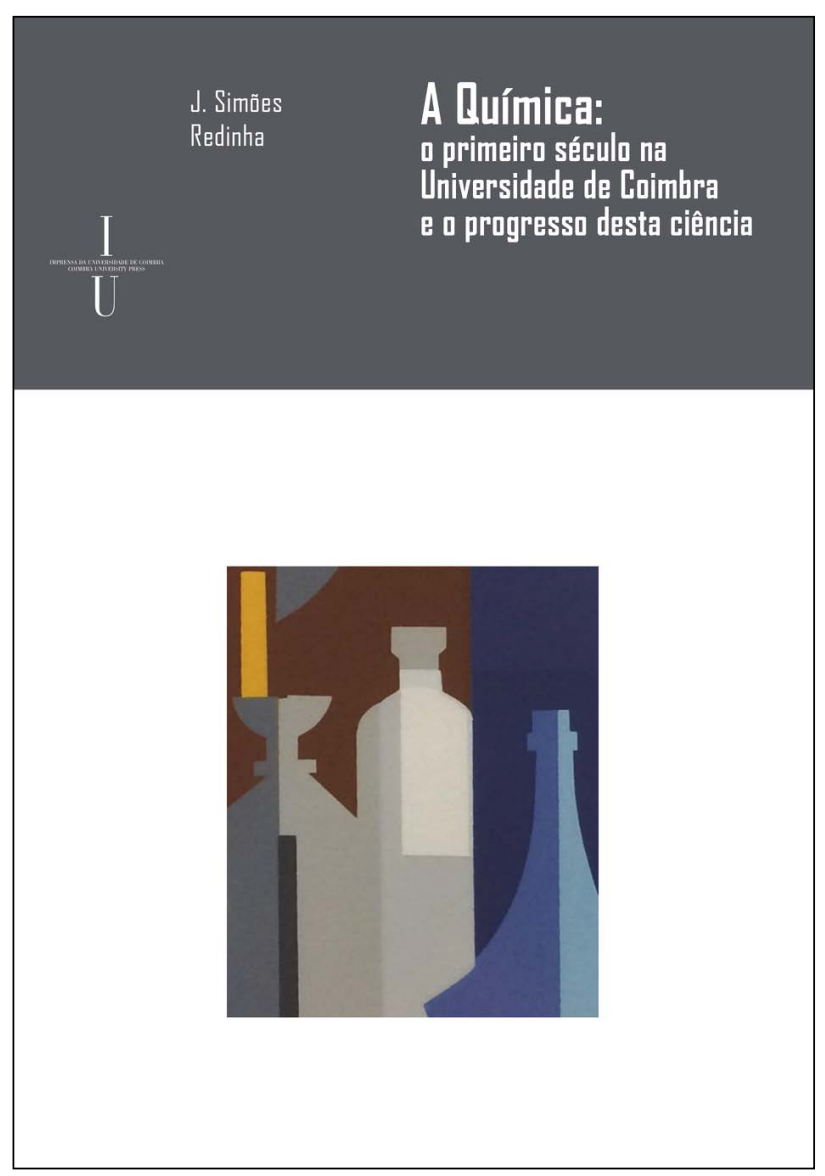

Imprensa da Universidade de Coimbra

ISBN: 978-989-26-1874-6

elSBN: 978-989-26-1875-3

DOI: $10.14195 / 978-989-26-1875-3$

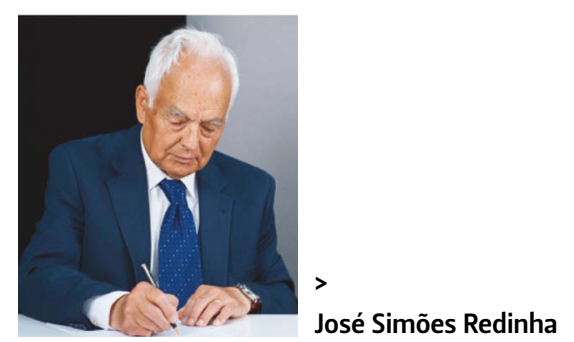

\section{Sobre o Autor}

José Simões Redinha é Professor Catedrático Jubilado da Universidade de Coimbra (UC), no Departamento de Química da FCTUC. Fez o seu percurso académico na Universidade de Coimbra e doutorou-se em 1958 na Universidade de Londres enquanto investigador no Imperial College of Science and Technology, na especialidade de Termodinâmica Química. Entre 1963 e 1966 contribuiu para o estabelecimento da Química na Universidade de Lourenço Marques, em Moçambique, cujos laboratórios equipou e dirigiu. Nos anos de 1972 a 1974, foi responsável pela introdução e arranque dos cursos de licenciatura em Engenharia na Faculdade de Ciências e Tecnologia da UC, na qualidade de seu primeiro Diretor, tendo ocupado idêntico lugar na Faculdade de Ciências, que a antecedeu. De 1980 a 1990, desempenhou, diversas vezes, o cargo de Presidente do Departamento de Química e da sua Comissão Científica. Executou ainda funções na EURATOM e na EUROCHEM, tendo sido responsável pela criação e direção de estruturas formais para ligacção da Universidade de Coimbra à indústria. É autor de mais de uma centena de publicações de ciência fundamental, ciência aplicada e didática, a maior parte das quais foram publicadas em revistas internacionais. É membro da Academia das Ciências de Lisboa desde 1979 e de várias associações científicas. A sua área de investigaçãa científica tem sido direcionada para o estudo das interações moleculares e iónicas, principalmente em soluções aquosas, e os seus efeitos energéticos, quer no domínio experimental, quer na interpretação teórica e físico-química. 